\title{
ОСОБЛИВОСТІ ПОРУШЕНЬ ПРОЦЕСІВ ПЕРОКСИДНОГО ОКИСНЕННЯ ЛІПІДІВ ТА АНТИОКСИДАНТНОГО ЗАХИСТУ В КРОВІ У ДИНАМІЦІ РОЗВИТКУ ІММОБІЛІЗАЦІЙНОГО СТРЕСУ ПРИ АДРЕНАЛІНОВОМУ УШКОДЖЕННІ МІОКАРДА
}

\begin{abstract}
Резюме. Стресові реакції організму людини та тварин - одна з найважливіших проблем сучасності, процеси адаптації до яких активно досліджуються. Гостре адреналінове ушкодження міокарда зумовлює розлади серцевої діяльності, які проявляються зниженням його помпувальної функції, що призводить до зменшення хвилинного об'єму серця.

Мета дослідження - з'ясувати особливості динаміки змін показників пероксидного окиснення ліпідів та антиоксидантного захисту в крові у щурів за умов розвитку іммобілізаційного стресу та адреналінового ушкодження міокарда.

Матеріали і методи. Дослід проводили на білих щурах-самцях лінії Вістар масою 180-200 г, яких поділили на 4 групи по 10 тварин (одна контрольна та три дослідні). Стан процесів пероксидного окиснення ліпідів (ПОЛ) оцінювали за вмістом дієнових кон'югатів та малонового діальдегіду в крові, що визначали в різні періоди (1-ша, 3-тя і 5-та доби) після проведення іммобілізаційного стресу (IC) в щурів. Антиоксидантний захист (АОЗ) оцінювали за активністю ферментів каталази та супероксиддисмутази.

Результати досліджень та їх обговорення. Проведені комплексні біохімічні дослідження показників пероксидного окисненя ліпідів і антиоксидантної системи у тварин різних груп (інтактних, іммобілізаційний стрес, адреналінове ушкодження міокарда, окремо та в їх поєднанні), довели, що на всіх етапах їх формування відбувається поступове надмірне утворення продуктів ліпопероксидації на тлі зниження активності каталази і супероксиддисмутази (1-ша, 3-тя, 5-та доби) в крові, що вказує на розвиток оксидантного стресу.

Висновки. Проведений експеримент дозволив встановити суттєве порушення прооксидантної рівноваги у тварин за умов іммобілізаційного стресу та адреналінового ушкодженя міокарда.
\end{abstract}

Ключові слова: пероксидне окиснення ліпідів; антиоксидантний захист; іммобілізаційний стрес; адреналінове ушкодження міокарда.

ВСтУП Стресові реакції організму людини та тварин одна 3 найважливіших проблем у сучасності, процеси адаптації до яких активно досліджуються. Причиною стресу можуть бути різноманітні фактори, психологічне та/або соціальне напруження, біль, переохолодження тощо. Однак усі вони запускають подібні механізми відповіді на стрес, що спрямовані на підтримання сталості внутрішнього середовища організму [1]. Однією з ендогенних стресобмежувальних систем, що модулює стрес-реакцію та забезпечує адаптацію, є антиоксидантна система організму [2]. За дії стресу відбувається накопичення в крові продуктів вільнорадикального окиснення та активних фрорм кисню, зниження бусрерної ємності крові відносно підтримання оптимальних параметрів інтенсивності вільнорадикальних реакцій та перш за все зростають стресові гормони, зокрема адреналін [3, 4]. Гостре адреналінове ушкодження міокарда зумовлює розлади серцевої діяльності, які проявляються у зниженні його помпувальної фрункції, що призводить до зменшення хвилинного об'єму серця [5]. Найбільше рівень адреналіну зростає у крові й міокарді при його ішемії та гіпоксії, унаслідок стресу, що призводить до ішемічної хвороби серця. Таку шкідливу дію стресу та адреналіну на міокард можна пояснити такими їх ефектами: здатністю активувати процеси пероксидного окиснення ліпідів, накопиченням іонів кальцію, пригніченням захисту організму [6].

Метою дослідження було з'ясувати особливості динаміки змін показників пероксидного окиснення ліпідів та антиоксидантного захисту в крові у щурів за умов розвитку іммобілізаційного стресу та адреналінового ушкодження міокарда.

МАТЕРІАЛИ I МЕТОДИ Дослід проводили на білих щурах-самцях лінії Вістар масою 180-200 г, яких поділили на 4 групи по 10 тварин (одна контрольна та три дослідні). Щурам першої контрольної групи вводили срізіологічний розчин дозі 1 мг на 1 кг маси тіла внутрішньочеревно. Тварин другої дослідної групи піддавали іммобілізаційному стресу упродовж 3 год, виводили з експерименту через 1-шу, 3-тю і 5-ту доби, тваринам третьої дослідної групи вводили 0,18 \% розчину адреналіну гідротартату в дозі 1 мг на 1 кг маси внутрішньочеревно (О. О. Маркова 1998), виводили з експерименту через 1-шу, 3-тю і 5-ту доби, тварин четвертої дослідної групи піддавали тривалому іммобілізаційному стресу (3 год) та вводили внутрішньочеревно адреналін у такій самій дозі, виводили з експерименту через 1-шу, 3-тю і 5-ту доби.

Усіх експериментальних тварин утримували в стандартних умовах віварію Львівського національного медичного університету імені Данила Галицького. Дослідження проведені 3 дотриманням науково-практичних рекомендацій з утримання лабораторних тварин і роботи з ними та положень Європейської конвенції про захист хребетних тварин, що використовуються для дослідних та інших наукових цілей (Страсбург, 1986). Тварин декапітували під легким наркозом, викликаним тіопенталом натрію (внутрішньочеревне введення 1\% розчину 50 мг/ кг) і виводили з експерименту через 1-шу, 3-тю і 5-ту доби. У плазмі крові визначали активність каталази, супероксиддисмутази, дієнових кон'югатів та малоновий діальдегід у щурів 3 індукованим стресом і адреналіновим ушкодженням міокарда окремо та в їх поєднанні, дані групи порівнювали зі щурами контрольної групи.

Активність каталази (КТ) визначали за методом М. А. Королюк, Л. І. Іванова, І. Г. Майорова (1988) [7]. Визначення активності супероксиддисмутази (СОД) проводили за методом В. С. Гуревич, К. Н. Конторщікова, Л. В. Шатіліна (1990) [8]. Вміст дієнових кон'югатів (ДК) визначали методом В. С. Камишнікова (2000) [9]. Малоновий діальдегід (МДА) визначали методом Р. А. Тімірбулатова, Е. М. Селезнєва (1981) [10]. Іммобілізаційний стрес (IC) відтворювали за методом П. Д. Горизонтова, О.І.Бєлоусова, М. І. Фетодова (1983) [11]. Адреналінове ушкодження міокарда (АПМ) відтворювали за методом О. О. Маркової (1998) [5]. Статистичне опрацювання одержаних даних здійснювали з використанням критерію Стьюдента [12]. 
РЕЗУЛЬТАТИ ДОСЛІДЖЕНЬ ТА ЇХ ОБГОВОРЕВАНня Стан процесів пероксидного окиснення ліпідів оцінювали за вмістом ДК та МДА в крові, що визначали в різні періоди (1-ша, 3-тя і 5-та доби) після проведення IC у щурів. За умов розвитку IC спостерігали підвищення вмісту ДК на 116,96 \% $(p<0,05)$ у другій дослідній групі, відповідно на 1-шу добу після IC, порівняно з контролем. Після введення адреналіну рівень ДК зріс на 158,18 \% $(p<0,05)$ у третій дослідній групі проти інтактної групи тварин. Четверта дослідна група, що поєднує IC та введення АПМ, характеризується зростанням вмісту ДК на $212,72 \%(p<0,05)$ на 1-шу добу експерименту порівняно 3 контролем. Рівень ДК на 3-тю добу зріс на 53,93 \% $(p<0,05)$ при IC відносно інтактної групи, на 142,42 \% $(p<0,05)$ при АПМ проти контролю та на $178,78 \%(p<0,05)$ відповідно при поєднаній патології IC та АПМ порівняно з контролем. На 5-ту добу експерименту рівень ДК у всіх дослідних групах був вище на 44,24; 93,93; 125,45 \%, що показано на рисунку 1, відносно контролю.

Інший показник МДА в крові на 1-шу добу експерименту в другій дослідній групі зріс на 104,15 \% $(p<0,05)$ при IC відносно інтактної групи. За умов АПМ цей показник підвищився на 107,91 \% $(p<0,05)$ у третій дослідній групі, проти контролю. У четвертій групі тварин, в яких моделювали коморбідну патологію, зріс рівень МДА на 118,93 \% ( $<<0,05)$ порівняно з контролем. На 3-тю добу експерименту за умов розвитку IC рівень МДА підвищився на 83,9 \% $(p<0,05)$ проти контролю. При АПМ рівень МДА становив 59,86 \% $(p<0,05)$ на 3-тю добу порівняно 3 контрольною групою. За умов розвитку коморбідної патології на 3-тю добу значення МДА становило 86,77 \% відносно контролю. На 5-ту добу експерименту рівень МДА становив 30,1\% $(p<0,05)$ при IC, $26,4 \%(p<0,05)$ після АПМ та 13,32 \% $(p<0,05)$ при коморбідній патології порівняно з контролем (рис. 2).

Активність фрерментів антиоксидантного захисту (АОЗ) КТ та СОД мали протилежні зміни до ДК та МДА, зокрема вони зменшувалися на 1-шу добу експерименту в усіх трьох дослідних групах ( $<<0,05)$, причому найбільше у четвертій дослідній групі - КТ на 17,22 \% $(p<0,05)$ та СОД на $26,21 \%(p<0,05)$ проти контролю. Ці ензими у динаміці на 3-тю та 5-ту доби поступово знижувалися, зокрема на 3-тю добу вони склали у четвертій дослідній групі $-25,14 \%(p<0,05)$ та $-27,37 \%(p<0,05)$ відповідно порівняно 3 інтактною групою тварин. Найнижчі рівні цих показників спостерігали на 5-ту добу, при коморбідній патології (IC та АПМ) і складали відповідно -36,70 \% (p<0,05) та $-31,06 \%(p<0,05)$ порівняно з контролем. Активність КТ та СОД показано на рисунках $3,4$.

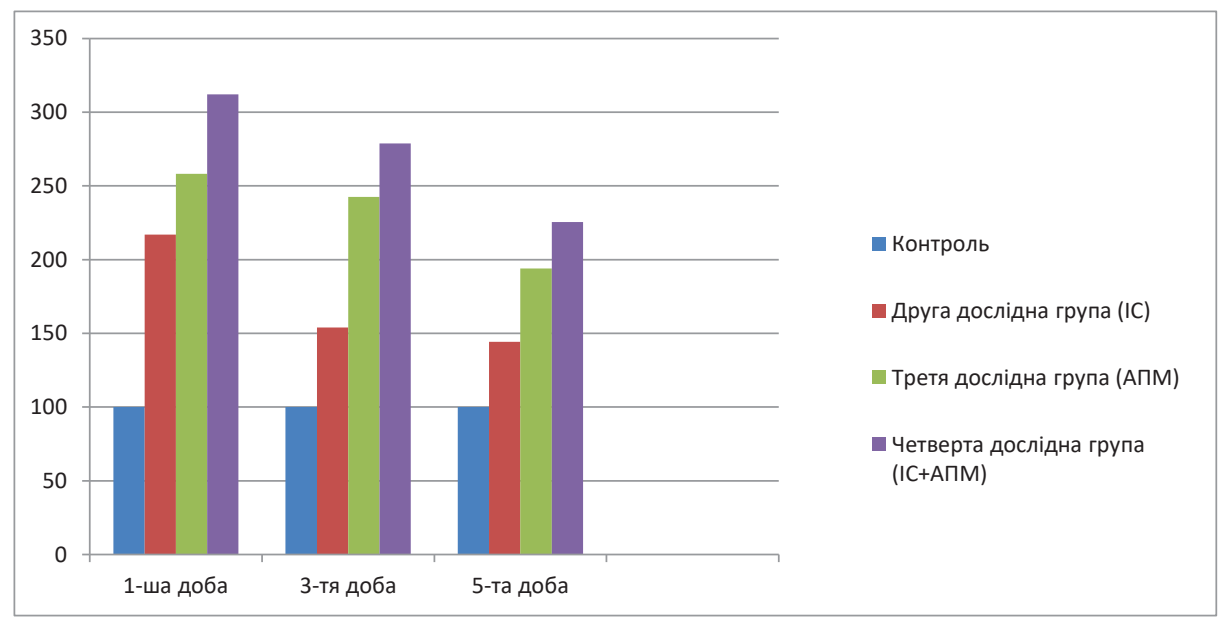

Рис. 1. Концентрація дієнових кон'югатів у крові щурів у динаміці розвитку іммобілізаційного стресу та адреналінового ушкодження міокарда (у \% від контролю).

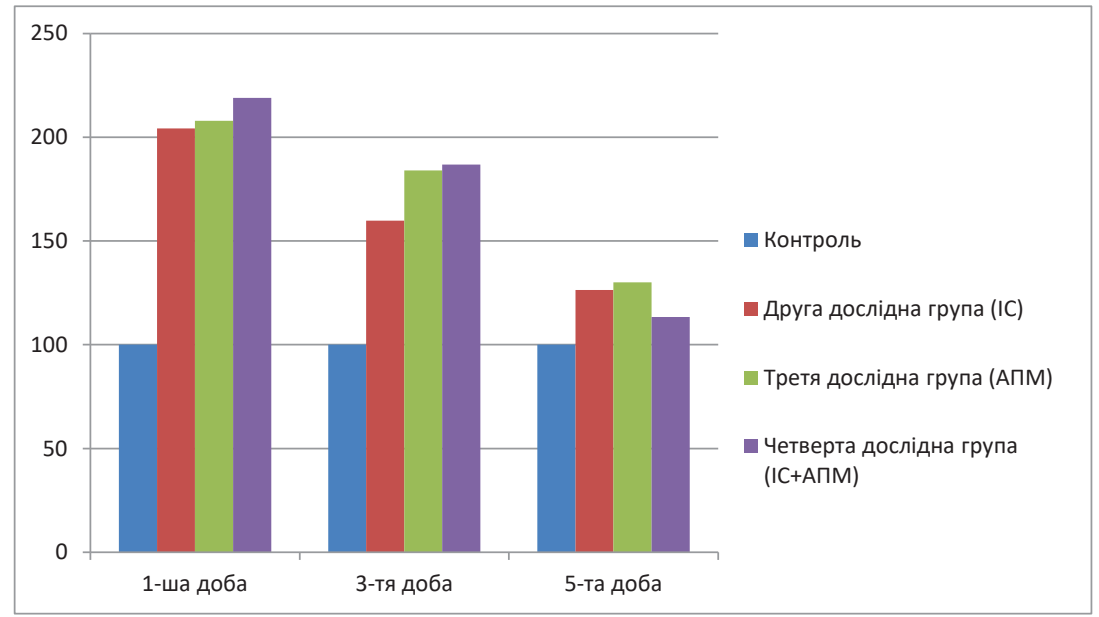

Рис. 2. Вміст малонового діальдегіду в крові щурів у динаміці розвитку іммобілізаційного стресу та адреналінового ушкодження міокарда (у \% від контролю). 


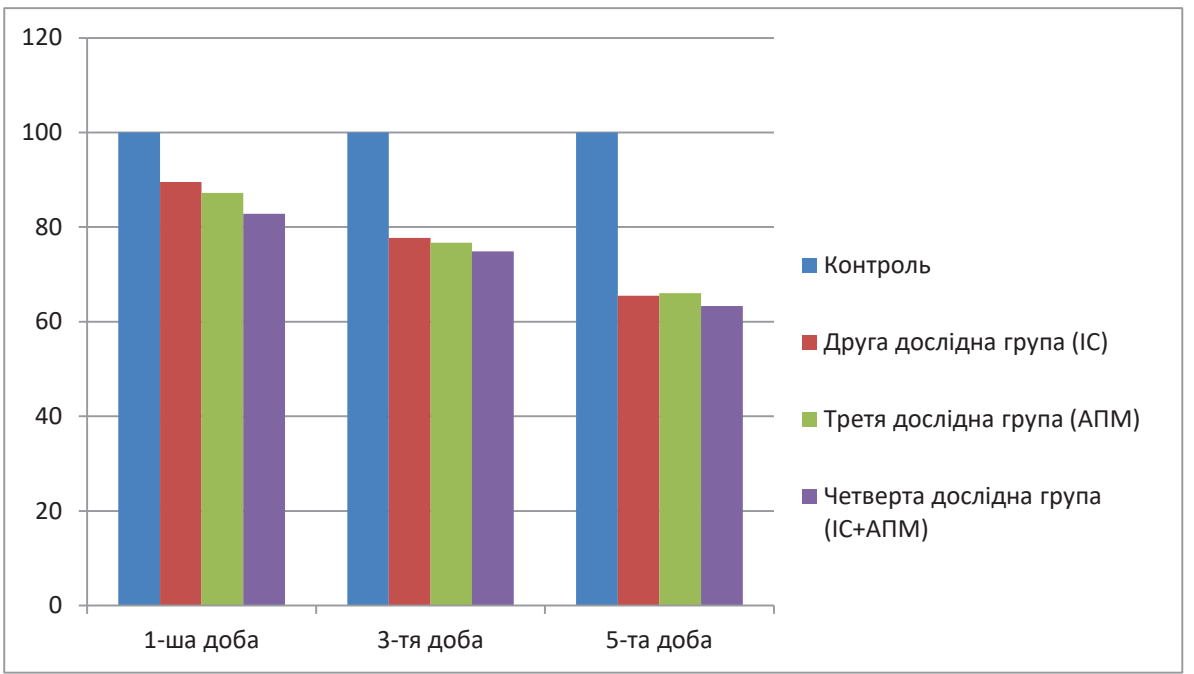

Рис. 3. Активність каталази в крові щурів у динаміці розвитку іммобілізаційного стресу та адреналінового ушкодження міокарда (у \% від контролю).

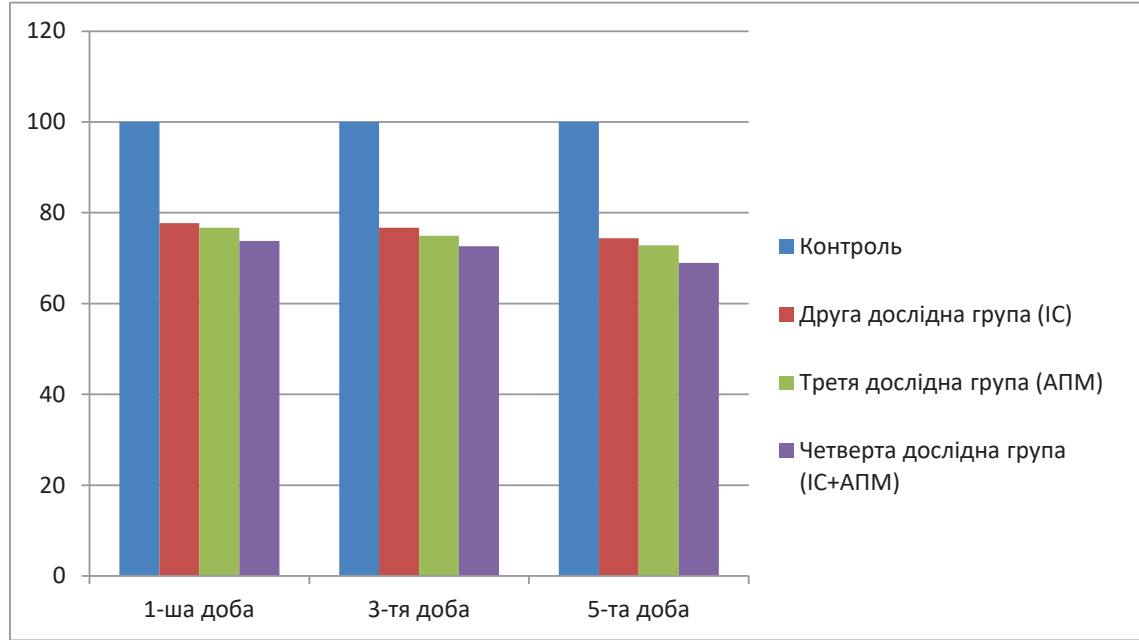

Рис 4. Активність супероксиддисмутази в крові щурів у динаміці розвитку іммобілізаційного стресу та адреналінового ушкодження міокарда (у \% від контролю).

ВИсновкИ Проведені комплексні біохімічні дослідження показників ПОЛ і АОЗ у тварин різних груп (інтактних, IC, АПМ, окремо та в їх поєднанні) на 1-шу, 3-тю, 5-ту доби показали, що на усіх етапах їх формування відбувається поступове надмірне утворення продуктів ліпопероксидації на тлі зниження активності КТ і СОД (1-ша, 3-тя, 5-та доби) в крові, що вказує на розвиток оксидантного стресу. Отже, проведений експеримент

\section{СПИСОК ЛІТЕРАТУРИ}

1. Барабой В. А. Фізіологія, біохімія і психологія: монографія / В. А. Барабой, О. Г. Резніков. - К. : Інтерсервіс, 2013. - 314 с.

2. Стешенко М. М. Динаміка змін прооксидантно-антиоксидантного балансу в мітохондріях міокарду та мозку щурів за умов іммобілізаційного стресу / М. М. Стешенко, О. О. Гончар, І. М. Маньковська // Досягнення біології та медицини. - № 1 (25). - 2015. - C. 31-34. дозволив встановити суттєве порушення прооксидантної рівноваги у тварин за умов IC та АПМ.

Перспективи подальших досліджень Визначення порушення процесів пероксидного окиснення ліпідів (ДК, МДА) та антиоксидантної системи (КТ, СОД) в крові у щурів за умов іммобілізаційного стресу та адреналінового ушкодження міокарда може слугувати важливим критерієм корекції цих порушень антиоксидантами та сприяти нормалізації антиоксидантного захисту.

3. Free radicals and antioxidants in normal physiological function and human disease / M. Valko, D. Leibfritz, J. Moncol [et al.] // Int. J. Biochem. Cell. Biol. - 2007. - Vol. 39 (1). - P. 44-84.

4. Sahin E. Immobilization stress in rat tissues: Alterations in protein oxidation, lipid peroxidation and antioxidant defense system / E. Sahin, S. Gumuslu // Comparative Biochemistry and Physiology Part C: Toxicology \& Pharmacology. - 2007. - Vol. 144, No. 4. - P. 342-347. 
5. Маркова О. О. Міокардіодистрофрія і реактивність організму / О. О. Маркова // Тернопіль : Укрмедкнига, 1998. - 152 с.

6. Сусла О. Б. Вікові зміни метаболізму в серцевому м'язі щурів у динаміці розвитку адреналінової міокардіодистрофії / О. Б. Сусла // Мед. хімія. - 2004. - № 1. - С. 41-47.

7. Метод определения активности каталази / М. А. Королюк, Л. И. Иванова, И. Г. Майорова [и др.] // Лабораторное дело. 1988. - № 1. - С. 16-19.

8. Гуревич В. С. Сравнительный анализ двух методов определения активности СОД / В. С. Гуревич, К. Н. Конторщиков, Л. В. Шатилина // Лаб. дело. - 1990. - № 4. - С. 44-47.
9. Справочник по клинико-биохимической лабораторной диагностике. - 2-х т. / под ред. Камышникова В. С. - Минск, 2000. - C. 205-206.

10. Тимирбулатов Р. А. Метод повышения интенсивности СРО липидо - содержащих компонентов крови и его диагностическое значение / Р. А. Тимирбулатов, Е. М. Селезнев // Лабораторное дело. - 1981. - № 4 - С. 209-211.

11. Горизонтов П. Д. Стресс и система крови / П. Д. Горизонтов, О. И. Белоусова, М. И. Фетодов. - М. : Медицина, 1983. - 338 с.

12. Ткач $€$. І. Загальна теорія статистики. - $€$. І. Ткач, В. П. Сторожук. - К. : Центр навчальної літератури, 2009. - 440 с.

Отримано 05.08.18

Електронна адреса для листування: tolstyakyaroslav@gmail.com

(c). B. Lys, M. S. Regeda, O. I. Hrushka

Danylo Halytskyi Lviv National Medical University

\section{FEATURES OF LIPIDS PERIPHERAL OXIDATION AND ANTIOXIDANT PROTECTION DISORDERS IN BLOOD IN THE DYNAMICS UNDER IMMOBILIZATIONAL STRESS DEVELOPMENT DURING ADRENALIN MIOCARDIAL DAMAGE}

Summary. Stress reactions of the human body and animals are one of the most important problems of the present time, the processes of adaptation to which are actively explored. Acute epinephrine myocardial damage causes heart disease disorder, which manifests itself in lowering of its suppressive function, which leads to a decrease in cardiac output.

The aim of the study - to find out the peculiarities of changes of lipid peroxidation and antioxidant blood levels in rats under conditions of development of immobilization stress and adrenal damage of myocardium.

Materials and Methods. The experiments were carried out on white male rats of the Vistar line weighing $180-200 \mathrm{~g}$, which were divided into 4 groups 10 animals in each (one control and three tested). The state of the processes of lipid peroxidation (LPO) was assessed by the content of new conjugates and malonic dialdehyde in the blood, which were determined at different periods $\left(1^{\text {st }}, 3^{\text {rd }}\right.$, and $5^{\text {th }}$ day) after the IP in rats. Antioxidant protection (AOP) was evaluated by activity of catalase and superoxide dismutase enzymes. Results and Discussion. Complex biochemical studies of lipid peroxidation and antioxidant system in animals of different groups (intact, immobilization stress, adrenal damage of myocardium, separately and in their combination) showed that consistently excessive formation of products of lipoperoxidation occurs on the background of decrease in activity at all stages catalase and superoxide dismutase formation $\left(1^{\text {st }}, 3^{\text {rd }}\right.$, and $5^{\text {th }}$ day) in the blood, indicating the development of oxidative stress.

Conclusions. Consequently, the experiment conducted allowed to establish a significant violation of the prooxidant balance in animals under conditions of immobilization stress and adrenal damage to the myocardium.

Key words: lipid peroxidation; antioxidant defense; immobilization stress; adrenal damage to the myocardium.

СОО. Б. Лис, М. С. Регеда, О. И. Грушка

Львовский национальный медицинский университет имени Данила Галицкого ОСОБЕННОСТИ НАРУШЕНИЙ ПРОЦЕССОВ ПЕРЕКИСНОГО ОКИСЛЕНИЯ ЛИПИДОВ И АНТИОКИДАНТНОЙ ЗАЩИТЫ В
КРОВИ В ДИНАМИКЕ РАЗВИТИЯ ИММОБИЛИЗАЦИОННОГО СТРЕССА ПРИ АДРЕНАЛОВОМ ПОВРЕЖДЕНИИ МИОКАРДА

Резюме. Стрессовые реакции организма человека и животных - одна из важнейших проблем современности, процессы адаптации к которым активно исследуются. Острое адреналиновое повреждения миокарда вызывает расстройства сердечной деятельности, проявляющиеся в снижении его насосной функции, что приводит к уменьшению минутного объема сердца.

Цель исследования - выяснить особенности динамики изменений показателей перекисного окисления липидов и антиоксидантной защиты в крови у крыс в условиях развития иммобилизационного стресса и адреналинового повреждения миокарда.

Материалы и методы. Опыт проводили на белых крысах-самцах линии Вистар массой 180-200 г, которых разделили на 4 группы по 10 животных (одна контрольная и три опытных). Состояние процессов перекисного окисления липидов (ПОЛ) оценивали по содержанию диеновых конъюгантов и малонового диальдегида в крови, определяли в различные периоды (1-е, 3-и и 5-е сутки) после проведения иммобилизиционого стресса (ИС) у крыс. Антиоксидантную защиту (АОЗ) оценивали по активности фрерментов каталазы и супероксиддисмутазы.

Результаты исследований и их обсуждение. Проведенные комплексные биохимические исследования показателей перекисного окисленного липидов и антиоксидантной системы у животных разных групп (интактных, иммобилизационный стресс, адреналиновое повреждение миокарда, отдельно и в их сочетании), доказали, что на всех этапах их фрормирования происходят последовательное избыточное образование продуктов липопероксидации на фоне снижения активности каталазы и супероксиддисмутазы (1-е, 3-и, 5-е сутки) в крови, что указывает на развитие оксидантного стресса.

Выводы. Эксперимент позволил установить существенное нарушение прооксидантного равновесия у животных в условиях иммобилизационного стресса и адреналинового повреждения миокарда.

Ключевые слова: перекисное окисление липидов; антиоксидантная защита; иммобилизационный стресс; адреналиновое повреждения миокарда. 